\title{
Portfolio Evaluation of Academic Patent: A Proposal to Brazil
}

\author{
Rafael Angelo Santos Leite ${ }^{1^{*}}$, Iracema M. de A. Gomes ${ }^{2}$, Suzana L. Russo ${ }^{3}$ and Cicero C. S. Walter ${ }^{4}$
}

\begin{abstract}
In the current context of scarce financial resources, technology transfer offices are pressured to find ways to increase revenues through technology transfers or reduce expenses with their portfolio of technologies, especially patents. The Patent assessment seeks to detect the market potential of patents for transfer through licensing, abandonment, or maintenance. In this context, the objective of this study is to validate the leading indicators used in the patent evaluation to develop a framework for evaluating academic patent portfolio in the Brazilian context. For this, we used mapping and analysis methods of the current models besides focus group consultations, exploratory factorial analysis, and Analytical Hierarchy Process (AHP) to validate the indicators. The results show that seven factors are determinant in the evaluation of academic patents, having positive implications for the management of Intellectual Property since technology transfer decision-makers can use the factors and their identified weights as value indicators to evaluate patents with the most significant market potential.
\end{abstract}

Keywords: Patent Value Assessment; Validation of Indicators; Multiple Criteria Decision Making; Analytical Hierarchy Process

Submitted: March $5^{\text {th }}, 2019$ / Approved: November $8^{\text {th }}, 2019$

\section{Introduction}

The Innovation Law 10.973/2004 and Law 13.243/2016 established the Center of Technological Innovation in Brazil, a structure set up by Science and Technology Institutions (STI) to manage the institutional policy of innovation, in addition to other competencies of the new lawful support.

In Brazil, however, the centers undergo structuring processes, and there is still no way to effectively manage the portfolio of assessment or valuation technologies for their licensing. Thus, there are low economic benefits. In times of scarce financial resources, technology transfer offices are pressured to find ways to increase revenues through technology transfers or reduce expenses with their portfolio of technologies, especially patents.

Patent evaluation is a useful tool to detect its market potential and contributes to portfolio management decision making. In this paper, we present some results of the patent portfolio evaluation in the international literature (Grimaldi, Cricelli, \& Rogo, 2018; Hsieh, 2013/2; Santiago, Martinelli, Eloi-Santos, \& Hortac, 2015; B. Wang \& Hsieh, 2015/3). A common feature in the development of these models is to look for the most relevant indicators of patent analysis.

Patent appraisal models are particularly suitable for institutions dealing with an extensive portfolio. It is even more appropriate when one doesn't have many resources to evaluate each of them through a personalized approach using quantitative methods (Santiago et al., 2015). Identifying valuable patents within an organization's patent portfolio is a crucial issue for intellectual property managers (Wang \& Hsieh, 2015/3). If a Science and Technology Institution (STI) achieves the know-how to evaluate a technology value through patent analysis, then it can conduct better marketing and cost-effective strategies, it will be able to make decisions rightly (Hsieh, 2013/2).
In this context, the aim of this article is to validate the leading appropriate indicators for the evaluation academic patent portfolio in the context of Brazil and contribute to the technology transfer processes, presenting a general evaluation model for Brazilian Science and Technology Institutions that may also be useful for similar cases in other Latin American countries with related limitations in terms of their ability to produce technologies from academia to market (Hansen, Agapitova, Holm-Nielsen, \& Vukmirovic, 2002; Lee \& Kim, 2018; Navarro, Benavente, \& Crespi, 2016).

Besides this brief introduction, this paper has four sections. In the next section, In the next section, we present the theoretical framework with main concepts that guide the development of a proposal for evaluating academic patents. Then, the methodology is described, the results obtained, considered as the central point of this paper, and the conclusions and suggestions of future researches.

\section{Theoretical references}

\section{Intellectual Property Management}

Science and Technology Institutions (STI) have collaborated with patent applications around the world. In the case of Brazil, there is growth, although discontinuous, of patents number coming from universities (Amadei \& Torkomian, 2009). Despite the distance from Brazil, Russia, India, China, and South Korea - BRICS (Thimoteo, 2013), universities in Brazil have been advanced both in the number of the patent application and into intellectual property (IP) management (Amadei \& Torkomian, 2009; Mueller \& Perucchi, 2014).

Identifying valuable patents within an organization's patent portfolio is a key issue for IP managers (Wang \& Hsieh, 2015/3). "Patents continue to be one of the most readily available and reliable sources of information to evaluate a technology" (Hsieh, 2013/2, p. 307), so it is necessary for the manager to understand the value of his patent portfolio, and thus, to manage it strategically (Grimaldi et al., 2015/5).

$(1,4)$ Business and Management Department, Federal Institute of Piauí, Teresina/PI, Brazil

$(2,3)$ Postgraduate Program in Intellectual Property Science, Federal University of Sergipe, São Cristóvão/SE, Brazil.

*Corresponding author: rafaelangelo@ifpi.edu.br 
The analysis of the "perceived value of a patent portfolio can clearly help the decision-making process and define the best protection strategy of a company" (Grimaldi et al., 2015/5, p. 287), however, it is not easy for IP managers to estimate the value without market information, especially university patents, since they are generated from science-oriented research projects that are generally far from ready for commercialization (Hsieh, 2013/2).

The study by Póvoa \& Rapini (2010) on technology transfer from Science and Technology Institutions in Brazil concluded that "about $45 \%$ of the interactions refer to the transfer of the new process and techniques, while new transfers of products represent 29.4\% (Póvoa \& Rapini, 2010, p. 18), demonstrating that universities and research institutes generate technologies that are not sources of new products ready for commercialization.

When one achieves the ability to evaluate the price of technology through patent analysis, it is possible to predict the priorities concerning patents already filed and new invention proposals, as well as to advise managers on the technological fields for better investments in research and development projects (Hsieh, 2013/2).

Several patent portfolio evaluation models have been proposed (Grimaldi et al., 2015/5; Hsieh, 2013/2; Lee \& Sohn, 2016; Santiago et al., 2015; B. Wang \& Hsieh, 2015/3). A common feature in the development of these models is the search for more relevant indicators to offer the best analysis. These indicators are based on existing literature, as well as the opinion of experts and focus groups. Next, the models used to assess the potential of patents will be addressed.

\section{Patent Assessment Models}

In order to properly manage intellectual property, organizations must be able to measure and evaluate the value of their patent portfolios (Hanel, 2006/8), and the establishment of patent indicators is key to patent analysis (Tseng, Hsieh, Peng, \& Chu, 2011/2). The retrieval and evaluation of patent data should be institutionalized within the organization (Ernst, 2003).

These are indicators related to the value of patents: citations received from subsequent patents, the number of references to the patent literature, measures of family size, and successful defense against annulment claims and opposition proceedings (Harhoff, Scherer, \& Vopel, 2003). Also, "the greater the breadth of patent scope, the stronger of patents impact on the value of the company" (Hanel, 2006/8, p. 925). Tseng et al., (2011/2) ranked patent indicators from previous studies into three types according to the purpose (why), technology strategy (how), and value produced (what). The indicators related to market potential, i.e., the value provided, were: patent age, corporate market value, backward reference, forward citation, family size, scope, owner, number of claims, patenting strategy, number of applications, number of co-operation between researchers, number of key inventors, and legal disputes.

Considering a statistical approach, indicators such as forward citation, grant decisions, patent families, renewals, and oppositions are used to assess the value of patents (Van Zeebroeck, 2011). He elaborated a ranking among a set of similar patents using these five indicators, synthesizing them into a single value (percentage indicator) from 1-100.

Nam, Nam, \& Kim (2015/6) investigated the financial effect or stock value resulting from patent processes between Apple and other smartphone manufacturers such as Samsung and High Tech Computer Corporation (HTCC). The result showed that patents in litigation might have added value.

Considering that detecting promising academic research is vital for companies in a variety of industries (Ogawa \& Kajikawa, 2015/1) if a patent is within a promising area, this has additional relative value. Liu, Cao, \& Song (2014) conducted a lifetime patent analysis and the Chinese patent renewal between 1985 and 2005 and found that the patent value varies between different technological areas considerably. Wang, García, Guijarro, \& Moya (2011) calculated the relative importance of patents for a group of companies in a specific industry. This importance was calculated using seven (7) indicators. These include the age of patent, the extent of protection, citations made from the patent and received by other subsequent patents, number of claims, and patent family size.

The Hsieh (2013/2) presents a hybrid method of evaluating patents and determining the strategy in the initial stage of commercialization. In this model, the target audience is Research Institutions with a patent portfolio, and the leading benefit is to establish strategic actions directed to each group of patents in the portfolio, increasing their chances of commercialization. The 20 indicators used were subjected to a factorial analysis that resulted in 4 groups of indicators: General Management Benefits (Goodwill, Revenues, Social Welfare, Licensing opportunities, Industrial clustering or Networking completeness, Spin-offs Opportunities, Business Diversification, and Research and Development (R\&D) effort and staff); General Management Risks (managerial risk, increased technological risk - i.e., certification, meeting standards -, market acceptance risk, technological development or production risk, market risk, and increased expenses due to litigation); Offensive Benefits (income due to litigation, citation of patents, and market share); and Cost-Related Risks (Cost, Patent application and maintenance costs, and Expenses.

The model developed by Santiago et al., (2015), 'The framework for assessing the portfolio of technologies for licensing out', was proposed for large corporations to analyze their portfolio of patented technologies and subsequently establish royalty rate values to support the negotiation process. At this point, it serves as the rationale for the negotiation of large patent volumes. Indicators used were: Breadth (Geographical coverage), Licensing limitations (legal, strategic or technical limitations), value generation potential criterion (Technical and Marketing Aspects). The impact of marketing was divided into potential, trends, and burdens.

The authors believe that this framework is of great value to universities as well as to their technology transfer offices. Once the reference 
values for royalty rates have been provided, potential licensors and the university can deal with the negotiation from that rate (Santiago et al., 2015).

A model proposed by Grimaldi et al., (2015/5), 'The patent portfolio value analysis: a new framework to leverage patent information for strategic technology planning, is a practical and replicable evaluation model that removes strategic patent information combining economic- with bibliometric-technological details, in order to support the decision-making process of patent managers and verify their compliance with the technological and innovative strategy in the company. They use determinants of patents value that are extracted from patent databases: Technical scope; Forward citation frequency; International scope; Patenting strategy; and Economic relevance. The model makes it possible to suggest which strategic changes can improve the value of the portfolio, or which significant actions should be implemented, such as portfolio licensing or sales, rather than technology production. For Grimaldi et al., (2015/5, p. 287), the portfolio value refers to the "power of the portfolio to support the company's value creation process and its strategic business objectives." The study by Wang \& Hsieh (2015/3) resulted in the model 'Measuring the value of patents with fuzzy multiple criteria decision making.' The authors re-examined the criteria used by model researchers to evaluate patent portfolios. The authors concluded that these criteria were incomplete, differed widely between studies, were not always independent, assessed only a small number of patents, and, in general, they were from a specific sector. The indicators of Wang \& Hsieh (2015/3) are a) Strategic Patent Values (innovation, technology competitiveness, business potential, and organizational growth; b) Patent protection values (Quality and residual life cycle); and c) Values of marketing (new products initiated in relevant industries or not). These groups were called objectives and are inspired by the patent measurement system of Yet2.com.

The result of the Wang \& Hsieh (2015/3) model is the patent classification into three types: Class A (highly valuable), Class B (intermediate values), and Class C (low). After this classification, it is possible to establish strategic actions for patents. Two examples of decisions suggested in this model are 1) patents with very high scores (class A) the suggestions can be plans for licensing or for new venture initiatives; and 2) for patents with low scores in category $\mathrm{C}$, auctioning or dropout are suggested because of the minimal patent-related opportunities.

Another model (Lee \& Sohn. 2016), called 'Patent portfolio-based indicators to evaluate the commercial benefits of national plant genetic resources', is a patent evaluation framework based on the proposition of specific indicators that estimate the commercial value by the use of genetic resources in the biotechnology industry. Some indicators of this model have been established in terms of marketing (Impact Dimension - The diversity of related industry and nationality of inventors/applicants; Cost-Effectiveness Dimension - Patent family size, related industry scale and export; number of citations for forward and backward, Dimension Growth - Current impact, growth rate of patent applications and Dimension Exclusivity - Number of species of the same genus registered in Union for the Protection of New Varieties of Plants (PNVP). The result of this study is a map of value correlating the aspect of 'Technology' with that of 'Marketing' relative portfolio of Korean genetic resources that can help the State and users in the benefits-sharing agreements.

Considering that the model offers identification of the relative value rather than the exact monetary value of the patents, its leading contribution was to provide useful references for use as a reference point during the negotiation of benefit-sharing agreements (Lee \& Sohn, 2016).

A detailed analysis of these models allows us to understand that they use some value indicators that do not always differentiate the value of patents produced by Science and Technology Institutions in contexts of developing economies such as Brazil, where patents have, for example, fewer cases of litigation, little interest in defending the market and reduced family size. A quick analysis using Orbit software shows that the number of international applications arriving in Latin American countries is much higher than those coming from here to the world, showing that patents in this region tend to have a small family (Orbit, 2019), moreover, the share of these international patents assigned to universities, institutes or individuals is small (Chakrabarti \& Bhaumik, 2015). In this sense, this research aims to present a general model for patent evaluation that is useful for Brazilian Science and Technology Institutions, not excluding the possibility of application by institutions present in other Latin American countries with similar intellectual property generation dynamics (Fuquen \& Escobar, 2018), as well as those who have, along with Brazil, Universities in the list of the top 500 in the world (e.g. Chile and Argentina) (Academic Ranking of World Universities, 2018).

\section{Research Methodology}

This research proposes to validate the leading indicators used in the patent evaluation to develop a framework for evaluating academic patent portfolios in Brazilian, through into three specific objectives:

Specific objective n.1: Map the existing patent portfolio evaluation models published in the ScienceDirect database (2009-2016), using terms related to assessment, assessment, value, valuation, evaluation or evaluation and patent or technologies with the following command 1: pub-date $>2009$ and TITLE assess $^{\star} \mathrm{OR}^{\star}$ valu$^{\star}$ AND patent ${ }^{\star}$ OR technolog* AND portfolio). This command brought two important papers for the begging of this research because they presented relevant details and information to support the use of keywords to delimited the scope of the present research. They are 1) "The patent portfolio value analysis: A new framework to leverage patent information for strategic technology planning". (Grimaldi et al. 2018); and 2) "A framework for assessing a portfolio of technologies for licensing out" (Santiago et al. 2015). In command 2, excluded the term 'portfolio, obtaining a sample of 8 articles: (Van Wyk, 2010/4), (Wang et al., 2011), (Dunn, Luke, \& Nassar, 2013/3), (Kontogianni, Tourkolias, \& Skourtos, 2013/4), (Grimaldi et al., 2015/5), (Santiago et al., 2015), (Lee \& Sohn, 2016) and (Song, Seol, \& Park, 2016/2). The next search, 
command 3, taken out the exigency of the "portfolio" term. As the sample was extensive (1,780 articles), the search was limited by the topics "patent, technology assessment", obtaining, then, 85 articles. Afterward, these articles were classified in three ways: 1) Is it a patent portfolio assessment model with similar indicators to other models?; 2) Do you propose any of the leading evaluation indicators?; and, 3) Doesn't directly collaborate with the research objectives, but can be useful for methodology, method, analysis of results, others.

The specific objective n. 2: List the indicators most used in the models. After identifying similarities between 54 (fifty-four) indicators present in the models, these were grouped into a list of 18 (eighteen), they are: (1) Term of Patent Expires (Santiago et al., 2015); (2) Patent Family Size, or Geographical Scope of Protection (Grimaldi et al., 2015/5; Santiago et al., 2015; Suzuki, 2011/9); (3) Number of Claims (Grimaldi et al., 2015/5; Lee \& Sohn, 2016; Suzuki, 2011/9; Wang \& Hsieh, 2015/3); (4) Formal Limitations on Commercializing (Santiago et al., 2015); (5) Litigation (Hsieh, 2013/2); (6) Number of Citations (Grimaldi et al., 2015/5; Lee \& Sohn, 2016; Suzuki, 2011/9); (7) Need of High Initial Investment (Hsieh, 2013/2; Santiago et al., 2015); (8) Need for certification and compliance with many standards (technological risk) (Hsieh, 2013/2); (9) Risk of market acceptance (Hsieh, 2013/2); (10) Market risk (eg changes in prices or market rates) (Hsieh, 2013/2); (11) Size of the market (Grimaldi et al., 2015/5; Santiago et al., 2015; Wang \& Hsieh, 2015/3); (12) Economic relevance (Grimaldi et al., 2015/5); (13) Patent strategy (Grimaldi et al., 2015/5); (14) Impact of technology on industry (Level of innovation) (Santiago et al., 2015; Wang \& Hsieh, 2015/3); (15) Superiority/competitiveness of technology in relation to substitutes (Santiago et al., 2015; Wang \& Hsieh, 2015/3); (16) Market trend (Hsieh, 2013/2; Santiago et al., 2015); (17) Technology with the patent has already been licensed (Wang \& Hsieh, 2015/3); (18) The technology has already been transformed into product or process (in start ups or spin-off) (Hsieh, 2013/2, Wang \& Hsieh, 2015/3).

And, specific objective n.3: Validate the leading indicators for the evaluation of academic patents. The indicators were submitted to judgments according to their influence on the value of academic patents. Cronbach's Alpha was applied to guarantee the reliability of the data collection instrument (Maroco \& Garcia-Marques, 2013). The result obtained was 0,789 , which indicates reasonable reliability between 0,7 and 0,8. We used the Exploratory Factor Analysis method of the 18 criteria, with the student version of the Statistical Package for the Social Sciences (SPSS) software, obtaining 7 (seven) main components (Hair, Black, Babin, Anderson, \& Tatham, 2009; Saunders, Lewis, \& Thornhill, 2007).

After finding these 7 (seven) possible factors, the next step was to find the relevance of each on the market value of patents in Brazil. Wang et al., (2011) used weights obtained quantitatively by mathematical, statistical, and computational equations. Other authors determined these weights by interviews using questionnaire research with experts (Hsieh, 2013/2; Lee \& Sohn, 2016; B. Wang \& Hsieh, 2015/3). This research obtained the weights using the Analytical Hierarchical Process' method. AHP is a method of solving a problem with multi-criteria with qualitative and quantitative characteristics (Saaty, 1990). Since subcriteria are structured hierarchically, decision-makers assign a level of importance to each criterion through comparisons of pairs to produce scores, which are the weights for the indicators.

\section{Sample definition and data collection}

Brazil is the Latin American country with the most Universities in the top 500 ranking of 2018 (Academic Ranking of World Universities, 2018), two of which - the University of São Paulo and University of Campinas - are among the most respected universities in Latin America by managing the Technology Transferences process through their Technologies Transferences Officers (Dias \& Porto, 2018). Given the similarities in the dynamics of intellectual property generation with other Latin American countries (Fuquen \& Escobar, 2018), consulting experts from the higher-yielding Brazilian science and technology institutions means, to some extent, capturing the expertise of capable professionals reflect the similar and positive characteristics of Latin American innovation systems (Lee \& Kim, 2018), as well as their patterns of technological expertise (less dynamic and stagnant technologies) over the last decades compared to other emerging economies such as Asia (Urraca-Ruiz, 2019).

The sample of experts consulted in this research was composed of 39 professionals, among managers of technology transfer offices or experts on this subject. To reach this number, a form with questions was sent to the estimated population of this sample, for a total of 428 (four hundred and twenty-eight) people. This was done through contact with Intellectual Property Associations in Brazil: Academic Association of Intellectual Property (AIP) of the State of Sergipe, Intellectual Property Association of São Paulo (IPASP), Brazilian Association of Intellectual Property Agents (BAIPA), National Association of Research and Development of Innovative Companies (NARDIC) Brazilian Intellectual Property Association (BIPA), Postgraduate Program in Intellectual Property (PPIP) of the Federal University of Sergipe (FUS), PROFINIT Program, and professionals from Centers of Technological Innovation of Science and Technology Institutions (public or private). In this step, the percentage of responses was only $9.13 \%$. To reach the specific objective 3 (validation of the indicators), the second collection (Step 2) was carried out with a focus group using another questionnaire. There were 23 respondents in this 2nd step.

A limitation regarding the selection of the sample of this research is the number of respondents of step 1 that, according to Hair et al., (2009), preferably a factorial analysis is performed with a sample greater than or equal to 100 and, as a general rule, the minimum is to have at least five times more observations than the number of variables to be analyzed, conditions that are not respected by the sample of the present study, so that the Exploratory Factor Analysis performed is indicative of possible factors. 


\section{Results and discussion}

Step 1 of the research: focus group consultation and factorial analysis

In order to identify the leading determinant factors to the evaluation of academic patents, an Exploratory Factorial Analysis was applied on 18 (eighteen) indicators most commonly used in models to evaluation patents. The Kaiser-Meyer-Olkin (KMO) and Bartlett tests are found to be 0,563 an less than 0,001 , respectively. These results show that the Factorial Analysis is useful, allowing reject the hypothesis of the identity of the correlation matrix, i.e., that the variables are correlated to the level of significance of $5 \%$. So, it is possible to proceed with the Factorial Analysis. After analyzing all the assumptions for the application of the factor analysis, it is observed that some variables have values of sample adequacy below 0.5 , however, as the communities after extraction have values higher than 0.5 , if not remove them. For the extraction of the factors, the principal components method was chosen. To identify the number of factors, the Kaiser and Pearson criteria were applied, resulting in 7 factors with their own values greater than 1 (one) and a variance cumulative percentage of $71.06 \%$ in the total variance.

In order to facilitate the interpretation of the factors, a factor rotation was performed according to the Varimax method to maximize the values of the factorial loads so that each variable is associated to only one factor. Table 1 shows that Factor 1 brought together the indicators Litigation, Market Risk, Patent Licensed Technology and Technology Transformed into Product explains $24.07 \%$ of the total variance, thus being the most important factor. The other factors explain, respectively: Factor 2 explains $12.37 \%$ of the total variance; Factor 3 explains 10.33\%; Factor 4 explains 9.94\%; Factor 5 explains 7.86\%; Factor 6 explains 6.31\%; and finally, Factor 7 explains $5.48 \%$ of the total variance.

In table 1 it's possible to visualize the results of Step 1: Focus group consultation and factorial analysis.

Table 1. Summary of Exploratory Factor Analysis for patent assessment criteria

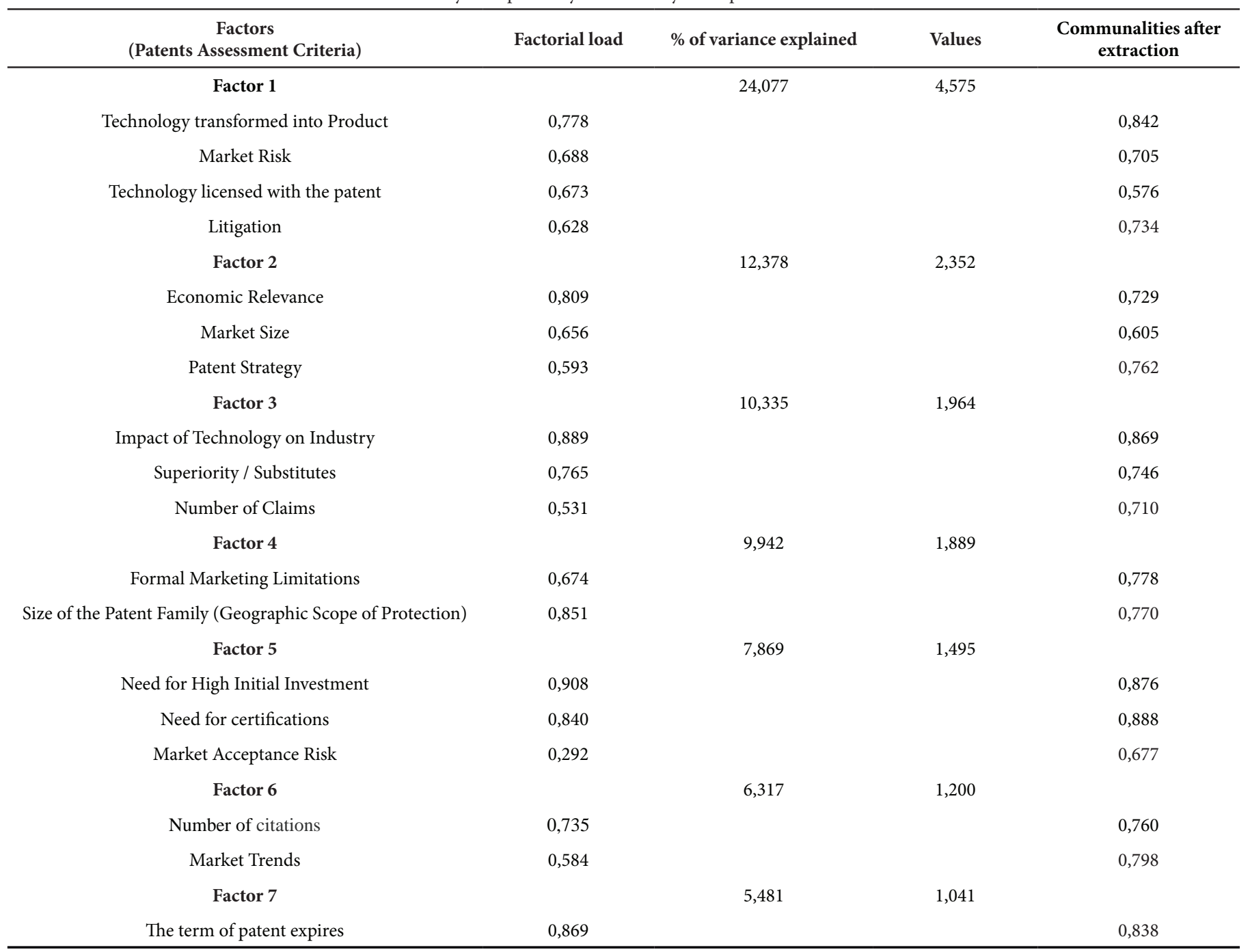


Looking at Table 1, some highlights deserve attention. Litigation presented the lowest factor load in the 'Factor 1' group, indicating that it is not a relevant criterion to determine the value of patents in Brazil, unlike studies in other markets (Agliardi \& Agliardi, 2011, Allison, Lemley, Moore, \& Derek Trunkey, 2003; Hsieh, 2013/2, Zhang, Lv, \& Zhou, 2014/3). The explanation can be the shortage of legal processes involving academic patents in Brazil.

'Patenting Strategy' is a factor-only support criterion, unlike other studies (Grimaldi et al., 2015/5; Suzuki, 2011/9) that have a prominence in the value of the patent when they have the potential to block. This result is justified by the inherent characteristics of the academic patents since they come from research without interest to defend some market dominated by technology, as it happens in private companies of high technological intensity.

'Number of claims' had the lowest factor load factor 3, demonstrating only to be a criterion supporting factor 3. This result differs from other studies (Grimaldi et al., 2015/5; Lee \& Sohn, 2016; Suzuki,
2011/9 (Wang et al., 2011). Perhaps if the term presented to the experts was 'Quality of claims' (Wang Wang \& Hsieh, 2015/3), the result could be different.

The lowest factor load was 'Market Acceptance Risk' (0.292). The explanation may be related to the profile of academic patents that are, in general, embryonic (Jerry G. Thursby, Jensen, \& Thursby, 2001) and more process-focused than products. And when related to products, it generally has no potential to create new markets and therefore the experts consulted do not come with this criterion with a strong relation to the value of patents in the context of Brazil' ICT.

Finally, another highlight was the 'Number of citations' (forward and backward) criterion that has a high factorial load, indicating that it is relevant to determine the value of patents in Brazil, confirming most of the international studies related to this criterion (Grimaldi et al. al., 2015/5, Lee \& Sohn, 2016, Suzuki, 2011/9).

Factors have been renamed and their definitions are presented in Table 2:

Table 2. Factors renamed from the factorial load of the independent criteria

\begin{tabular}{|c|c|}
\hline Factors renamed & Independent criteria / Factorial load \\
\hline Factor 1 - 'Expectations regarding the level of technological maturity' & $\begin{array}{l}\text { Technology Transformed into Product: } 0,778 \text {; } \\
\text { Technology Licensed with Patent: } 0,673 \text {; } \\
\text { Market Risk: } 0,688 \text {; and Litigation: } 0.628\end{array}$ \\
\hline Factor 2 - 'Expectations regarding the financial return of the investment' & $\begin{array}{l}\text { Economic Relevance: } 0,809 ; \\
\text { Market Size: } 0.656 ; \text { and } \\
\text { Patenting Strategy: } 0.593\end{array}$ \\
\hline $\begin{array}{l}\text { Factor } 3 \text { - 'Expectations regarding the competitive advantage of technology } \\
\text { in its segment and its superiority over substitutes' }\end{array}$ & $\begin{array}{l}\text { Impact of Technology on Industry: } 0,889 \text {; } \\
\text { Superiority in relation to Substitutes: } 0.765 \text {; and Number of Claims: } 0.531\end{array}$ \\
\hline Factor 4 - 'Expectations regarding the Patent Family Size' & $\begin{array}{l}\text { Size of the Patent Family (Geographic Protection Range): } 0.851 \text {; and } \\
\text { Formal marketing restrictions: } 0,674\end{array}$ \\
\hline $\begin{array}{l}\text { Factor } 5 \text { - 'Expectations regarding the high initial investments to start pro- } \\
\text { duction and meet certification requirements' }\end{array}$ & $\begin{array}{l}\text { Need for High Initial Investment: } 0.908 \text {; } \\
\text { Requirement of Certifications: } 0,840 \text {; } \\
\text { Market Acceptance Risk: } 0.292 \text {. }\end{array}$ \\
\hline Factor 6 - 'Expectations regarding the patent quality in terms of citations' & $\begin{array}{l}\text { Number of Citations: } 0.735 \text {; } \\
\text { Market Trend: } 0.584\end{array}$ \\
\hline Factor 7 - 'Expectations regarding the remaining time of the patent" & Deadline for the Patent Expires: 0.899 \\
\hline
\end{tabular}

According to Table 2, the proposed definitions for the factors after factorial rotation are:

Factor 1: Considering that the variables with the highest factor load were 'Technology Transformed into Product' $(0,778)$ - related to the distance (or time) necessary for the technology to be ready for commercial application (Jerry G. Thursby et al., 2001) - this factor was renamed as 'Expectations regarding the status of technological maturity'. In this context, the other variables are support for this factor, especially when a patent is already licensed, since it indicates a higher level of maturity (J. G. Thursby \& Thursby, 2007) and interaction with industry (Pojo, 2014); or when a patent is in the process of litigation, since it indicates greater value perceived by the litigants (Allison et al., 2003).

Factor 2: Considering that the variables with the highest factor load were 'Economic Relevance' (0.809) - which represents the sales of the patent in relation to the entire portfolio - and 'Size of the Market' (0.656) - which represents the expectation of sales -, this factor was renamed as 'Expectations regarding the financial return on the investment'. In this context, the other variable, 'Patenting Strategy', that indicates whether the patent has the function of conquering new markets and/or defending an organization's existing market (Grimaldi et al., 2015/5), function as support for increased sales expectations. 
Factor 3: Considering that the variables with the greatest factorial load were 'Impact of Technology in Industry' $(0,889)$ - which represents the level of technology innovation, that is, how strong is its competitive advantage in the segment - and 'Superiority in Relation to Substitutes' (Santiago et al., 2015; B. Wang \& Hsieh, 2015/3), this factor was renamed as 'Expectations regarding the competitive advantage of technology in its segment and its superiority in relation to substitutes'. In this context, the variable 'Number of Claims' is support to increase sales expectations, as the claims reflect the technological importance of innovation and the number of claims shows that innovation has a potential for profitability embodied in it (Grimaldi et al., 2015/5).

Factor 4: Considering that the variable with the highest factorial load was 'Patent Family Size' (0.851) - which indicates the number and types of countries/jurisdictions where the patent is protected (Fischer \& Leidinger, 2014/4; Grimaldi et al., 2015/5) - this factor was renamed as 'Expectations regarding the Patent Family Size'. In this context, the other variable, 'Formal Marketing Restrictions" is a limiting factor (Santiago et al., 2015).

Factor 5: Considering that the variables with the greatest factorial load were 'Need for High Initial Investment' (0.908) and 'Need for Certifications' (0.840) - bottlenecks that reduce the commercial potential of the patent (Santiago et al., 2015) - this factor was renamed 'Expectations regarding the high initial investments to start production and attend certification requirements'. In this context, the other variable, 'Market Acceptance Risk', acts as a support to factor, since the greater the Market Acceptance Risk' (eg technology without a defined market) the greater the investment to decrease this risk (Ferreira, 2013).

Factor 6: Considering that the variables with the highest factor load were 'Number of Citations' contained in the patent (Tantiyaswasdikul, 2014) or received by other patents (Chen \& Chang, 2009), this factor was renamed as 'Expectations regarding the quality of patent in terms of citations (back and forth)'. In addition, the Patent Citation variable is one of the 13 variables used in the trend analysis method of (Gao et al., 2013/3) and helps to estimate the future development of a technology from the technological life cycle, according to the identification of the emergent phases, growth, maturity, and saturation of the technology. For this reason, the other variable - 'Market Trend' functions as a support for this factor.

Factor 7: This factor includes a question related to the marketing limiter that is the remaining time of exploitation, being critical for patents with less than 5 years to expire (Santiago et al., 2015). For this reason, this has been renamed as 'Expectations regarding the remaining time of the patent'

The factors described in Table 2 were then grouped into a hierarchy with two sets (Technology x Market). For Wang et al., (2011), the analysis of the Science and Technology Institutions Portfolio for commercialization purposes is a problem of multiple criteria distributed in a hierarchical structure that can present by qualitative or quantitative characteristics. For this reason, the following item brings the analysis of the data through the Analytical Hierarchy Process (AHP).

\section{Step 2 of the research - Analytical Hierarchy Process (AHP)}

Determining a precise method for estimating the value of the patent is like a "Holy Grail" within patent studies and practices. "Several of the proposed approaches generally fall into one of two categories: (1) methods of financial assessment, or (2) non-financial valuation methods" (Torrance \& West., 2017, p. 472). The variables are grouped into 'technological value' and 'business value' (Liu et al., 2014) and it's indicates that for the analysis it needs a method for problems with multi-criteria. Considering that the Analytical Hierarchy Process (AHP) is a method of solving a problem with multicriteria containing qualitative and quantitative characteristics (Saaty, 1990), the paired comparison of the factors in Step 1 generated the matrices in the graph of figure 1 .

Figure 1. Matrices after peer comparison and ranking of relevance

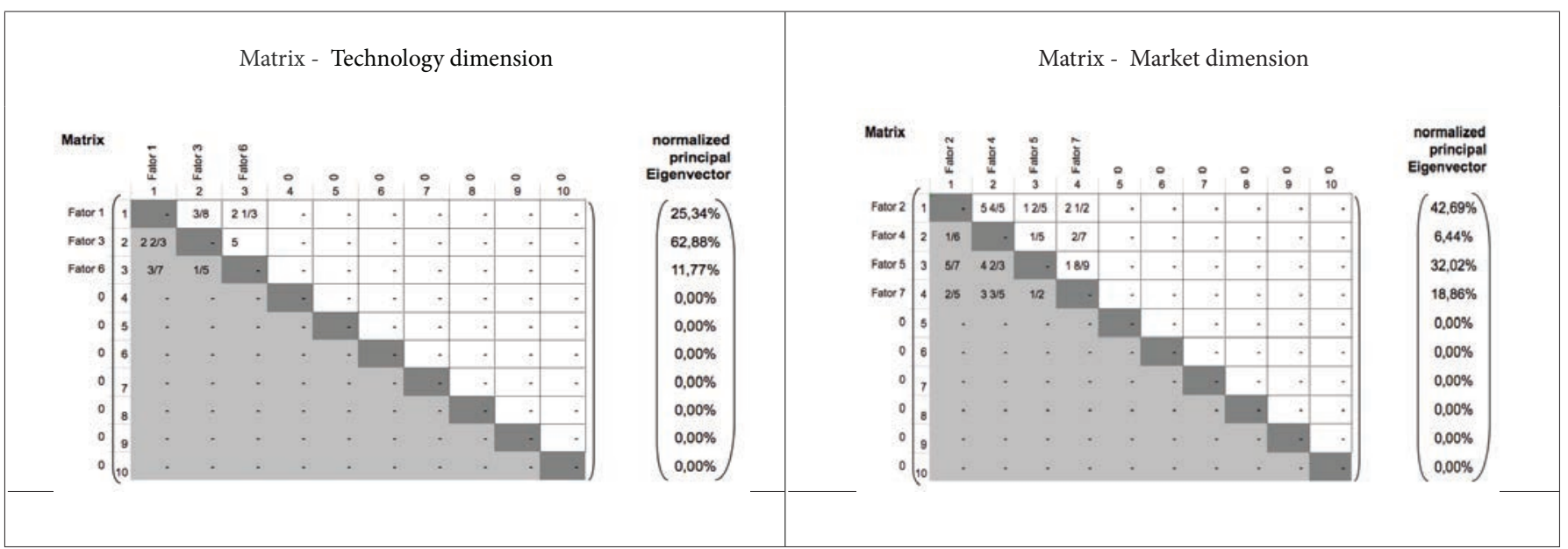

Adapted of Goepel (2013) 
The Figure 1 (left side) shows that, after adding all the comparisons in pairs (Factor $1 \times$ Factor 3, Factor $1 \times$ Factor 6, Factor 6 x Factor 3 ) of all specialists, the result was that Factor 1 has a weight of $25.34 \%$, Factor 3 has a weight of $62.88 \%$ and Factor 6 has a weight of $11.77 \%$.

This means that among the factor from the technology dimension that more interfere in the value of a patent, Factor 3 is the strongest.
By adding all the comparisons in pairs (Factor $2 \mathrm{x}$ Factor 4 , Factor $2 \mathrm{x}$ Factor 5, Factor 2 x Factor 7, Factor 4 x Factor 5, Factor 4 x Factor 7 , Factor $5 \mathrm{x}$ Factor 7) from responses of all the specialists, the result was that Factor 2 has a weight of $42.69 \%$, Factor 4 has a weight of $6.44 \%$, Factor 5 has a weight of $32.02 \%$, Factor 7 has a weight of $18,86 \%$. This means that among the factor from the marketing dimension that interferes in the value of a patent, Factor 2 is the strongest. The hierarchy of all the criteria and their weights that could be made with the technology and market dimension are expressed in figure 2.

Figure. 2. Hierarchy of all the criteria and their weights

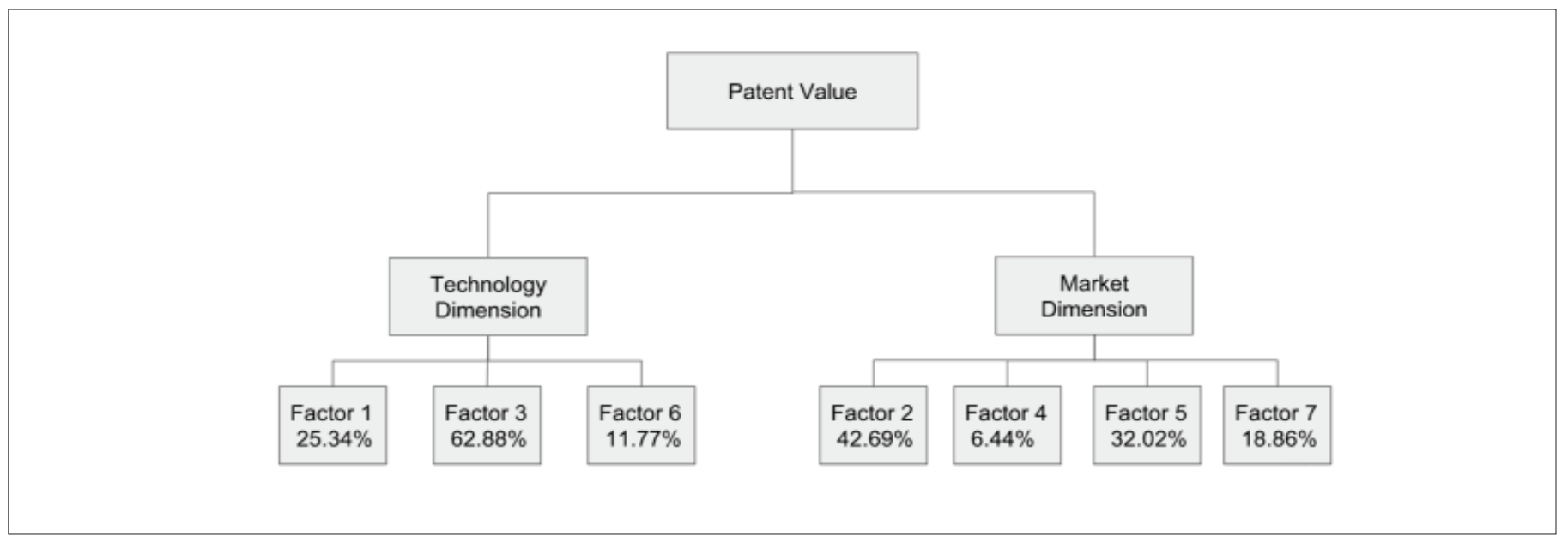

Subtitle:

Factor 1: Expectations regarding the level of technological maturity.

Factor 3: Expectations regarding the competitive advantage of technology in its segment and its superiority in relation to substitutes.

Factor 6: Expectations regarding patent quality in terms of citations (back and forward).

Factor 2: Expectations regarding the financial return on the investment.

Factor 4: Expectations regarding the patent family size.

Factor 5: Expectations regarding the high initial investments to start production and meet certification requirements.

Factor 7: Expectations regarding the remaining time spent on the patent

In Technology Dimension (Figure 2), factor 3 - Expectations regarding the competitive advantage of technology in its segment and its superiority in relation to substitutes - is highlighted with $62.88 \%$. This result proves that the power to generate technological advances, and consequently technological leadership in a given segment or in several segments, is strongly related to the potential of greater financial returns to academic patent in Brazilian context, confirming indicators of other studies (Santiago et al. al., 2015, Wang and Hsieh 2015).

Technological maturity (Factor 1 ) is the second most influential in patent value with $25.34 \%$. Considering that this factor is related to the time required for the technology to be ready for commercialization, involving proof of concept, laboratory-scale prototype, and proven manufacturing (Thursby; Jensen; Thursby, 2001), the explanation can be found in the study of Liu, Cao and Song (2014) that analyzed the motivation of the academic inventor/researcher and proved that it, in general, is to satisfy the academic performance, explaining, thus, both the factor influence in Brazilian context as the presence of it among all the indicators of technology already confirmed in the literature.
In the third position is 'Expectations regarding patent quality in terms of citations' (Factor 6). Despite of many studies support the positive influence this factor on patent value (Tantiyaswasdikul, 2014; Grimaldi, Cricelli, Di Giovanni, \& Rogo, 2015/5; Hsieh, 2013/2; Lee \& Sohn, 2016; Suzuki, 2011/9; Harhoff, Scherer, \& Vopel, 2003; Chen \& Chang, 2009; Wang, García, Guijarro, \& Moya, 2011) it has to observed in context of patent technological life cycle (Gao et al., 2013/3) and considering that the number of citations is strictly dependent on the patent age (citation lag) (Grimaldi et al., 2015/5), it can explain the 3 third position in the technology dimension.

Yet, given the Market Dimension, "Expectations regarding the financial return on investment" (Factor 2) stand out as more relevant (approximately 43\%). This factor has a different combination of indicators obtained by Lee and Sohn (2016) in rentability dimension, and different from (Grimaldi et al (2015), Wang \& Hsieh (2015), but this is not a question of a current financial return, but of the expectation of return, since Brazilian academic patents are not generating financial resources, mostly. The influence in the value is explained because 
one of the main interests of investors, that is, how much they can bill with the commercialization of new technology or product. The "Expectations for high initial investments to start production and meet certification requirements" (Factor 5) correspond to the second most relevant factor in the market dimension. This result is expected, as it corresponds to the following questioning of the majority investors regarding the market dimension, since the initial costs necessary for such marketing may represent a high risk.

The presence of factor 4 (Expectations regarding the size of the patent family) demonstrates its importance in patent value studies, but its low percentage relative to the other market dimension factors shows the need for its adjustment within the Brazilian and Latin American context. It is understood that this value indicator may be very relevant in other patent value models developed in more advanced markets (Grimaldi et al., 2015; Lee \& Sohn, 2016), but it is of little relevance to separate valuable and non-patent patents of academic patents from Brazil or other Latin American countries with economic similarities.

It stands out that figure 2 shows a consensus on the most relevant criteria for evaluating academic patents in a Brazilian context. Despite the experience or knowledge of these professionals, their judgments may be inconsistent), that is why the AHP that uses the Consistency Indicator (CI) to measure these discrepancies and the adequate tolerance of these inconsistencies (Wang \& Hsieh, 2015/3). The Consistency Indicator (CI) of the responses regarding the technology dimension factors was $0.5 \%$, with the limit being $5 \%$ for matrices with 3 factors - and to factors of the market dimension was $0.8 \%$ - is that the limit is $9 \%$ for matrices with 4 factors, thus, the CI of the 2 factors of the model is consistent.

The worksheet used to generate these results (Goepel, 2013) is limited to 20 judgments, so when this number was reached, some judgments were withdrawn and/or replaced, according to the degree of inconsistencies above the limits suggested by the AHP method, when isolated.

The calculation of the CI for each judgment separately is given by the equation:

CI $($ Consistency Index $)=$

$$
\frac{n M a x-n}{n-1}, \text { where } n \operatorname{Max}=\left[\sum_{L=1}^{n} \square \sum_{j=1}^{n} \square(a L, j . \text { Weight } L j)-n\right] /(n-I) \text { and } \mathrm{n}=
$$

The general result shows consistency with respect to the general order of importance for each group of factors involved (Saaty, 1990) since the consensus among the specialists was as follows: $75.6 \%$ for factors of the technology dimension and $77.4 \%$ for factors of the market dimension (Goepel, 2013).

\section{Final considerations}

This study used a review of the existing literature to identify 18 criteria (indicators) that may influence the value of academic patents. These criteria were subject to expert judgment when the influence of each on the market value of academic patents (Step 1). The reliability of the data was obtained using Cronbach's Alpha.
From the results of this first step 1, seven factors were extracted by exploratory factorial analysis and separated between factors of technology and market factors, similar to previous studies (Santiago et al., 2015). The Technology group brought together three factors and the 'Market group brought together four factors forming a hierarchy. In the second step of the research, a peer evaluation was made of each factor (technology factors with technology factors and market factors with market factors). For this, the AHP was used (a method to solve a problem with multiple criteria) and thus to define the relative importance (the weights) of each criterion to reveal the market potential of academic patents.

The prior analysis of a qualitative perspective that separates the most relevant patents within a portfolio facilitates the valuation process, although criticisms could be made to this research, concerning the criteria and the sample. One advantage of this study is that it considers the perspectives of several Technology Transfer (TT) experts, offering a consensus on the most relevant criteria to an assessment of the patent. An important contribution is a fact that these criteria are refined by adjusting value indicators that in the other developed models (e.g. Asia and Europe) has more relevance, but may not be useful in separating valuable and non-valuable patents in a portfolio of academic patents from Brazil or other Latin American countries.

For the decision-makers, the results of this study have positive implications for the management of Intellectual Property, since Technology Transfer Managers in Brazil can use the 7 factors and their weights identified - based on the existing literature, as well as the opinion of focus groups patents - to evaluate (identify) patents from the portfolios of Science and Technology Institutions (STI) with greater market potential. In addition, decision-makers form these Institutions through their patent application evaluation boards - can judge whether or not it is strategic to promote a patent application by their researchers internally. In this way, instruments for evaluating new applications for patents in research and innovation institutions could be improved based on these factors. Its usefulness would even reach the analysis of research projects for financing purposes, allowing, in a context of scarce resources in the Science and Technology Institutions, to invest in projects with the potential to generate more valuable patents.

Specific technology transfer strategic plans can be designed and structured using the results of this study. For example, a marketing plan may use the most relevant market factors and technology factors to better expose the patent to potential customers. Market and technology potential assessment software can be developed to help low-income Science and Technology Institutions to separate potential return patents for institutions that have invested so many resources in their lab and researchers throughout the development of their inventions.

For future studies, it is suggested to confirm the factors through a Confirmatory Factor Analysis in Brazil and Latin American countries, with Science and Technology Institutions with similar patent productivity. Also, it is suggested to develop a Structural Equation Model that can serve as a general parameter for Academic Patent Portfolio Assessments in the same context as this research. 


\section{References}

Academic Ranking of World Universities. (2018). Academic Ranking of World Universities 2018. Retrieved Out o4, 2019, from shanghairanking.com website: http://www.shanghairanking.com/ ARWU2018.html

Agliardi, E., \& Agliardi, R. (2011). An application of fuzzy methods to evaluate a patent under the chance of litigation. Expert Systems with Applications, 38(10), 13143-13148. https://doi.org/10.1016/j. eswa.2011.04.122

Allison, J. R., Lemley, M. A., Moore, K. A., \& Derek Trunkey, R. (2003). Valuable Patents. Georgetown Law Journal, 92, 435. https:// doi.org/10.2139/ssrn.426020

Amadei, J., \& Torkomian, A. (2009). As patentes nas universidades: análise dos depósitos das universidades públicas paulistas. Ciência Da Informação. Retrieved from http://www.scielo.br/pdf/ci/v38n2/01

Chakrabarti, A. K., \& Bhaumik, P. K. (2015). Technology development in Latin America and the Caribbean: an evaluation of the process in Brazil using patent data. International Journal of Technology Management $=$ Journal International de La Gestion Technologique, 68(3-4), 278-298. https://doi.org/10.1504/IJTM.2015.069641

Chen, Y.-S., \& Chang, K.-C. (2009). The Relationship between a Firm's Patent Quality and Its Market Value-the Case of US Pharmaceutical Industry. Technological Forecasting \& Social Change, 77, 20-33. https://doi.org/10.1016/j.techfore.2009.06.003

Dias, A. A., \& Porto, G. S. (2018). Technology transfer management in the context of a developing country: evidence from Brazilian universities. Knowledge Management Research \& Practice, 16(4), 525536. https://doi.org/10.1080/14778238.2018.1514288

Dunn, J. S., Jr., Luke, C., \& Nassar, D. (2013/3). Valuing the Resources of Infrastructure: Beyond From-Scratch and Off-the-Shelf Technology Options for Electronic Portfolio Assessment in First-Year Writing. Computers and Composition, 30(1), 61-73. https://doi.org/10.1016/j. compcom.2012.12.001

Ernst, H. (2003). Patent information for strategic technology management. World Patent Information, 233-242. Retrieved from http:// www.sciencedirect.com/science/article/pii/S0172219003000772

Ferreira, E. da S. (2013). Estudo de Fatores Precursores do Insucessos de Empresas Nascentes na Área das Tecnologias da Informação, Comunicações e Eletrônica em Portugal (Mestre). Instituto Universitário de Lisboa - ISCTE . Retrieved from https://www.researchgate.net/ profile/Edgar_Ferreira3/publication/283513341_Estudo_de_fatores_ precursores_do_insucesso_de_empresas_nascentes_na_area_das_ TICE_em_Portugal/links/563cb01908ae34e98c4aa126.pdf
Fischer, T., \& Leidinger, J. (2014/4). Testing patent value indicators on directly observed patent value-An empirical analysis of Ocean Tomo patent auctions. Research Policy, 43(3), 519-529. https://doi. org/10.1016/j.respol.2013.07.013

Fuquen, H. S., \& Escobar, E. S. O. (2018). A technology transfer strategy based on the dynamics of the generation of intellectual property in Latin-America. Intangible Capital, 203-252. https://doi.org/10.3926/ ic. 873

Gao, L., Porter, A. L., Wang, J., Fang, S., Zhang, X., Ma, T., ... Huang, L. (2013/3). Technology life cycle analysis method based on patent documents. Technological Forecasting and Social Change, 80(3), 398407. https://doi.org/10.1016/j.techfore.2012.10.003

Goepel, K. D. (2013). Implementing the analytic hierarchy process as a standard method for multi-criteria decision making in corporate enterprises - A new AHP excel template with multiple inputs. Bpmsg. com, p. 10. Retrieved from http://bpmsg.com/wordpress/wp-content/ uploads/2013/06/ISAHP_2013-13.03.13.Goepel.pdf

Grimaldi, M., Cricelli, L., Di Giovanni, M., \& Rogo, F. (2015/5). The patent portfolio value analysis: A new framework to leverage patent information for strategic technology planning. Technological Forecasting and Social Change, 94, 286-302. https://doi.org/10.1016/j.techfore.2014.10.013

Grimaldi, M., Cricelli, L., \& Rogo, F. (2018). Auditing patent portfolio for strategic exploitation: A decision support framework for intellectual property managers. Journal of Intellectual Capital, 0(ja), 00-00. https://doi.org/10.1108/JIC-01-2017-0019

Hair, J., Anderson, R. O., \& Tatham, R. (1987). Multidimensional data analysis. New York.

Hair, J. F., Black, W. C., Babin, B. J., Anderson, R. E., \& Tatham, R. L. (2009). Análise multivariada de dados - 6ed. Bookman Editora. Retrieved from https://market.android.com/details?id=book-oFQs_zJI$2 \mathrm{GwC}$

Hansen, T. N., Agapitova, N., Holm-Nielsen, L., \& Vukmirovic, O. G. (2002). The evolution of science and technology: Latin America and the Caribbean in Comparative Perspective. Background Paper for LCSHD.

Hanel, P. (2006/8). Intellectual property rights business management practices: A survey of the literature. Technovation, 26(8), 895-931. https://doi.org/10.1016/j.technovation.2005.12.001

Harhoff, D., Scherer, F. M., \& Vopel, K. (2003). Citations, family size, opposition and the value of patent rights. Research Policy, 32(8), 1343-1363. https://doi.org/10.1016/S00487333(02)00124-5 
Hsieh, C.-H. (2013/2). Patent value assessment and commercialization strategy. Technological Forecasting and Social Change, 80(2), 307-319. https://doi.org/10.1016/j.techfore.2012.09.014

Kontogianni, A., Tourkolias, C., \& Skourtos, M. (2013/4). Renewables portfolio, individual preferences and social values towards RES technologies. Energy Policy, 55, 467-476. https://doi.org/10.1016/j. enpol.2012.12.033

Lee, B. K., \& Sohn, S. Y. (2016). Patent portfolio-based indicators to evaluate the commercial benefits of national plant genetic resources. Ecological Indicators, 70, 43-52. https://doi.org/10.1016/j.ecolind.2016.05.002

Lee, K., \& Kim, Y. K. (2018). Comparing the National Innovation Systems in East Asia and Latin America: Fast Versus Slow. In T. Clarke $\&$ K. Lee (Eds.), Innovation in the Asia Pacific: From Manufacturing to the Knowledge Economy (pp. 63-82). https://doi.org/10.1007/978981-10-5895-0_3

Liu, L.-J., Cao, C., \& Song, M. (2014). China's agricultural patents: How has their value changed amid recent patent boom? Technological Forecasting and Social Change, 88, 106-121. https://doi.org/10.1016/j. techfore.2014.06.018

Maroco, J., \& Garcia-Marques, T. (2013). Qual a fiabilidade do alfa de Cronbach? Questões antigas e soluções modernas? Laboratório de Psicologia, 4(1), 65-90. https://doi.org/10.14417/lp.763

Mueller, S. P. M., \& Perucchi, V. (2014). Universidades e a produção de patentes: tópicos de interesse para o estudioso da informação tecnológica. Perspectivas Em Ciência Da Informação, 19(2), 15-36. https://doi.org/10.1590/1981-5344/1828

Navarro, J. C., Benavente, J. M., \& Crespi, G. (2016). The New Imperative of Innovation: Policy Perspectives for Latin America and the Caribbean. Retrieved from Inter-American Development Bank website: https://publications.iadb.org/en/handle/11319/7417

Nam, S., Nam, C., \& Kim, S. (2015/6). The impact of patent litigation on shareholder value in the smartphone industry. Technological Forecasting and Social Change, 95, 182-190. https://doi.org/10.1016/j. techfore.2015.01.015

Ogawa, T., \& Kajikawa, Y. (2015/1). Assessing the industrial opportunity of academic research with patent relatedness: A case study on polymer electrolyte fuel cells. Technological Forecasting and Social Change, 90, Part B, 469-475. https://doi.org/10.1016/j.techfore.2014.04.002

Pojo, S. da R. (2014). Proteção e licenciamento de tecnologias da Universidade: a experiência da UFRGS (Mestrado). Escola de Administração da UFRGS. Retrieved from http://hdl.handle.net/10183/98316
Póvoa, L. M. C., \& Rapini, M. S. (2010). Technology transfer from universities and public research institutes to firms in Brazil: what is transferred and how the transfer is carried out. Science \& Public Policy, 37(2), 147-159. https://doi.org/10.3152/030234210X496619

Questel. (2019). Sistema Orbit Inteligence [Questel Orbit, Inc].

Ribas, J. R., \& Vieira, P. R. da C. (2011). Análise multivariada com o uso do SPSS.

Saaty, T. L. (1990). How to make a decision: the analytic hierarchy process. European Journal of Operational Research. Retrieved from http://www.sciencedirect.com/science/article/pii/037722179090057I

Santiago, L. P., Martinelli, M., Eloi-Santos, D. T., \& Hortac, L. H. (2015). A framework for assessing a portfolio of technologies for licensing out. Technological Forecasting and Social Change, 99, 242251. https://doi.org/10.1016/j.techfore.2015.07.001

Saunders, M., Lewis, P., \& Thornhill, A. (2007). Research Methods for Business Students. (P. Hall, Ed.) (4th ed.). Inglaterra: Person.

Song, B., Seol, H., \& Park, Y. (2016/2). A patent portfolio-based approach for assessing potential R\&D partners: An application of the Shapley value. Technological Forecasting and Social Change, 103, 156165. https://doi.org/10.1016/j.techfore.2015.10.010

Suzuki, J. (2011/9). Structural modeling of the value of patent. Research Policy, 40(7), 986-1000. https://doi.org/10.1016/j.respol.2011.05.006

Tantiyaswasdikul, K. (2014). Determinants of Patent Value in US and Japanese University Patents. International Journal of Technical Research and Applications, 2(Special 4), 8-12. Retrieved from http:// www.ijtra.com/special-issue-view/determinants-of-patent-value-inus-and-japanese-university-patents.pdf

Thimoteo, T. (2013). Conhecimento represado. Revista Conjuntura Econômica, 67(5), 42-45. Retrieved from http://bibliotecadigital.fgv. br/ojs/index.php/rce/article/viewArticle/20671

Thoma, G. (2015). Trademarks and the patent premium value: Evidence from medical and cosmetic products. World Patent Information. Retrieved from http://www.sciencedirect.com/science/article/ pii/S0172219015000113

Thursby, J. G., Jensen, R., \& Thursby, M. C. (2001). Objectives, characteristics and outcomes of university licensing: A survey of major US universities. The Journal of Technology Transfer, 26(1-2), 59-72. Retrieved from http://link.springer.com/article/10.1023 /A:1007884111883

Thursby, J. G., \& Thursby, M. C. (2007). University licensing. Oxford Review of Economic Policy. Retrieved from http://oxrep.oxfordjournals.org/content/23/4/620.short 
Torrance, A. W., \& West., J. D. (2017). All Patent great and small: A big data network Approach to valuation. Virginia Journal of Law and Technology, 20(3), 39. Retrieved from http://vjolt.net/vol20/v20i3_1Torrance.pdf

Tseng, F.-M., Hsieh, C.-H., Peng, Y.-N., \& Chu, Y.-W. (2011/2). Using patent data to analyze trends and the technological strategies of the amorphous silicon thin-film solar cell industry. Technological Forecasting and Social Change, 78(2), 332-345. https://doi.org/10.1016/j. techfore.2010.10.010

Urraca-Ruiz, A. (2019). On the evolution of technological specialization patterns in emerging countries: comparing Asia and Latin America. Economics of Innovation and New Technology, 28(1), 100-117. https://doi.org/10.1080/10438599.2018.1433525

Van Wyk, R. J. (2010/4). Technology assessment for portfolio managers. Technovation, 30(4), 223-228. https://doi.org/10.1016/j.technovation.2009.06.005 van Zeebroeck, N. (2011). The puzzle of patent value indicators. Economics of Innovation and New Technology, 20(1), 33-62. https://doi. org/10.1080/10438590903038256

Wang, B., \& Hsieh, C.-H. (2015/3). Measuring the value of patents with fuzzy multiple criteria decision making: insight into the practices of the Industrial Technology Research Institute. Technological Forecasting and Social Change, 92, 263-275. https://doi.org/10.1016/j. techfore.2014.09.015

Wang, X., García, F., Guijarro, F., \& Moya, I. (2011). Evaluating patent portfolios by means of multicriteria analysis. Revista de Contabilidad, 14(1), 9-27. https://doi.org/10.1016/S1138-4891(11)70020-6

Zhang, G., Lv, X., \& Zhou, J. (2014/3). Private value of patent right and patent infringement: An empirical study based on patent renewal data of China. China Economic Review, 28, 37-54. https://doi. org/10.1016/j.chieco.2013.11.004 